\title{
Food Consumption Pattern and Nutrient Intake by the Fishermen Community of Ganjam District, Odisha
}

\author{
Suryamani Patro*, Brundaban Sahu and Bikash Kumar Pati \\ ${ }^{1}$ Department of Home science, SBRG Women's College, Berhampur, Odisha, India \\ ${ }^{2}$ College of Fisheries (OUAT), Rangailunda, Berhampur, Odisha, India \\ *Corresponding author
}

Keywords

Fishermen,

Nutritional status,

Food consumption

pattern, Nutrient

intake

Article Info

Accepted:

07 November 2020

Available Online:

10 December 2020

\section{A B S T R A C T}

Fisheries sector occupies very important role in the socio-economic development of the country. However, the fishermen community is one among the socially, economically and politically backward sections of the society. The physical well being of an individual is an indirect expression of its nutritional status, which is a cumulative expression of food consumption pattern and nutrient intake. It was in this context, the food consumption pattern and nutrient intake of fishermen community of Ganjam district, Odisha was assessed in this study. The study was done on randomly selected 122 fishermen families of Gopalpur-on-sea covering all economic groups and living standards. The data was collected through direct observation and personal interview method using pre-tested structured schedules and following seven day dietary cycle method. In the life of Nolias food does not play any important role in their life. Cereals like rice and ragi and non-veg like fish dominates their menu, while there was a significant deficiency noticed in the consumption of other food groups like fruits and vegetables; milk; nuts and oil seeds; egg, meat and poultry; spices and condiments etc. Locally brewed alcoholic beverage was found to be regularly consumed by adults. From the analysis of nutrient intake it is concluded that with the exception of energy and protein, the diet of the sample population was deficient in all other nutrients.

\section{Introduction}

Fisheries sector commands an important position in the socio-economic development of a country. It is getting well recognized as the source of livelihood for a large segment of economically downtrodden population, as it stimulates the growth of a number of subsidiary industries besides fishing. Accordingly, it is getting recognized as a powerful income and employment generator of any nation (Prabhavathi and Krishna, 2017). It is also well known as a foreign exchange earner, besides having a significant contribution to national Gross Domestic Product (GDP). Moreover, Fish and other aquatic animals make an 'irreplaceable' contribution to food and nutrition security in many Asian and African countries, where large numbers of people are poor and undernourished (Kent, 1987). Fish and fishery products are excellent source of good quality 
and easily digestible protein, a range of micronutrients, and fatty acids essential for human health (Tacon and Metian, 2013). They are often the cheapest and easily digestible animal-source protein that has a tremendous potential to provide food and nutritional security among down trodden and under privileged (Belton and Thilsted, 2014). In spite of the above facts, the producer of fish, the fishermen communities are often poor, physically isolated and with a little access to the public infrastructures and services or coverage by social policies (Prabhavathi and Krishna, 2017). It is one of the noted communities, where cases of malnourishment are often reported. Accordingly, a lot of studies have been undertaken keeping fishermen at their focal point.

Sehara et al., (1986) worked on the socioeconomic conditions of fishermen in some selected villages of Maharastra and Gujarat coast. Srinath (1989) made some observations on the food consumption pattern and nutritional status of marine fishermen community. Singh et al., (1995) worked on the social status and problems of fishing community at Allahabad. Pal et al., (2011) have reported that fishing community of Coastal Bay of Bengal is not only economically weak, but also find it difficult to procure the minimum nourishment. Bijayalakshmi and Ajitkumar (2014) have made a review on socio-economic conditions and cultural profile of the fishers in India and concluded that the socio-economic conditions of the fishers in India are considerably low. Fishers generally have pursued less education and live under improper housing conditions. With a very low income from fishing, fishers supported large members in the family, which compels the fishermen to borrow credits to fulfill their basic needs (Bijayalakshmi and Ajitkumar, 2014). Even in our neighboring country Srilanka, fishermen engaged in multi- day fishing suffer from the double burden of overweight and malnutrition together (Sandaruwan et al., 2016).

The physical well being of a person or community is an indirect expression of its nutritional status, which is a cumulative expression of food consumption pattern and nutrient intake. Fishermen and women, who fall in the category of heavy physical workers, have higher food and nutritional requirement compared to many other general populations. When the food is deficient in quantity or in terms of nutrient composition, the individual is bound to be affected with nutrient deficiency disorders. It was on this context, the food consumption pattern and nutrient intake of fishermen community of Ganjam district was assessed in this study.

\section{Materials and Methods}

Sample and sampling site: Gopalpur-on-sea of Ganjam Dist., a well known fish landing centre of South Odisha was selected as the representative sampling site and the fishermen community (Nolis) of the area was the targeted sample for the present study. One hundred and twenty two fishermen families were randomly selected, incorporating samples from all economic groups and living standard, for collection of data for this study.

Methods of data collection: The data for the present study was collected through direct observation and personal interview method. Pre-tested structured schedules were used to collect data on food habits and dietary practices being followed by the families including the meal pattern, frequency of food intake, details of traditional dishes being consumed along with the socio-economic background of the respondents. Family dietary intake was estimated following seven day dietary cycle method. 
Calculation of food and nutrient intake: Following the seven days dietary cycle method, the amount of raw food stuffs being consumed by the families in a week was calculated. It was then used to find out the daily consumption amount per family. These food stuffs were then categorised into nine different food groups based on their nutritive value. The per adult food consumption was then estimated from the diet of each family by using consumption coefficient based on the guidelines of Swaminathan (1988). It was then used to calculate the nutrient intake per adult per day using the food composition table of Gopalan et al., (1989).

\section{Results and Discussion}

\section{Life profile of the sample population}

The study was carried out at Gopalpur-onSea, Ganjam Dist, Odisha. A Total of 122 number of families from fisherman community comprising of about one third of the total fishermen population in the locality were selected randomly as the sample for the study. They are basically Telugu speaking people, Nolia by caste and Hindu by religion. Fishing is their major occupation. Generally elder male members of the family go for fishing in the deep sea, whereas female members are engaged in marketing and drying of fish. Besides fishing, some male members of the community are engaged in ancillary activities like boat making, repair of net and some also work as daily wage labourer in construction works. Similarly, some female members work as agricultural labourers particularly during the sowing and harvesting season. Some female members also work as daily wage labourers in construction works. They are socially backward people, leading low standard of living. They are mostly illiterates or less educated usually remaining away from any communication media such as T.V., radio, newspaper etc. Even today they depend on the community leader for getting in touch with the outer world. However, use of mobile smart phone is becoming popular these days and is being regarded as a status symbol among younger individuals of the community. This study has focused on their food consumption pattern and nutrient intake and the findings have been presented below.

\section{Food habit and dietary pattern}

The Nolias of the Gopalpur-on-Sea practice a typical food habit. In their life food does not play any important role. The sole purpose of food is just for survival. However, the role of food and liquor beverages assumes importance at the time of different festivals. In other days, a total absence of any concept of a special or varying menu was noticed. They continue with their limited menu in the routine food preparation for the major part of their life. The pattern of consumption of various food groups in their daily menu has been studied thoroughly and described below (Table 1).

Cereals and Millets: Cereals and millets constitute their staple food. Important among them are rice and ragi. These two serve as the major source of calorie, protein and vitamin-B Complex. Rice is consumed in the form of plain rice and also in broken form. Ragi flour along with broken rice is used in the preparation of their main dishes namely, Jau and Ambili. Besides, broken rice is also used in the preparation of a popular ethnic dish called Kanji.

Pulses: Pulses do not constitute a part of the regular food of the Nolias (Table 1). It is prepared occasionally. The occasional consumption of pulses may be attributed to the lower purchasing power of Nolias. The commonly consumed pulses include black gram and green gram in the form of dal. 
Fruits and vegetables: Fruit and vegetable are not the regular item in Nolia diet. Although, a variety of vegetables are included in their diet, there is a quantitative deficiency of these items (Table 1). The intake of fruits is very much negligible. Particularly, consumption of fruits like apple, orange and grape are rarely seen. They consider that these fruits are meant to feed bed ridden patients. The lower intake of fruits and vegetables may be due to their lack of awareness on the importance of fruits and vegetables as protective food, besides their poor economic standard. The lower intake of fruits and vegetables may be responsible for the wide gap in the vitamin and mineral content in their diet (Table 3).

Green leafy vegetables: The green leafy vegetables like drumstick leaves, Gogu, Kolam, Kosala formed a part of their regular diet. These are usually used in the preparation of curry or Kanji. Although these are the regular items in their menu, the intake level was found to be very low (Table 1). Lack of nutritional knowledge can be attributed as the main reason behind the lower intake of this food group. This may be the reason behind the occurrence of deficiency disorders like iron deficiency anaemia, vitamin-A deficiency (night blindness) and symptoms of Vitamin-B complex deficiencies among the sampled population.

Roots and tubers: The few most commonly used roots and tubers include potato, radish and onion. Onion is consumed in the raw form and also used during curry preparation. Potato and radish are the major ingredients of curry. Roots and tubers constituted the major calorie contributing groups next to cereals (Table -1)

Animal origin food: Nolias are nonvegetarian in their food habit. However, the only animal origin food taken by them is marine fish. Mutton, chicken etc. are usually consumed in festive occasions. Fish forms an important part of their diet. Marine fishes that fetch less price or that is difficult to sell are usually consumed by them, since the high value fishes are usually taken to market for selling. The variety of fishes being consumed by nolias are Sardines (Cavala), Ribbon fish (Savala), catfish (Kantia), Tuna (Tumuda), Mackerel (Kanagurta), Loligo (Kumutimuna), Gobi (Baligarida), Anchobvy (Kokuli), Vetki (Phathararundi) etc.

Milk, sugar and beverages: Milk and sugar are found to be consumed by nolias in negligible quantity. Adults usually take these in the form of tea. Infants in the home are given milk to some extent. Beside tea, the alcoholic beverage, particularly locally brewed liquor known as daru forms the regular beverage consumed by adults. The consumption of huge quantity of liquor by the sampled population may be attributed to their common belief that it is a source of enjoyment and energy and it takes away all the pains due to hard work.

Species and condiments: Green chilly and turmeric are the commonly used species. Tamarind is another frequently used spice in the preparation of most of their dishes after the extraction of its pulp. Use of other species was found very rarely. However, readymade curry powder available in the local grocery shop are seen to be used by some families occasionally.

Fat and oil: The use of fat and oil by the sample population is very negligible (Table 1). Nolias use fat and oil occasionally during the preparation of certain special dishes.

\section{Meal pattern}

Survey on meal pattern of nolia community showed that the adults of the community used 
to follow exclusively three meal pattern, taking breakfast, lunch and dinner. While in some cases children take snacks. Cereal, form the staple food in all the meals. In the breakfast they usually take leftover rice of last night with pickles and bhaji that is otherwise called as fermented rice. However, occasionally some male members of the community used to take breakfast outside the home. In such cases the items include Upma, Puri, Idly or bread accompanied with tea.
Lunch includes some cereal preparation like Ambili, Jau, plain rice accompanied with some side dishes like Kanji, chutney, Pulusu etc. When the adult male members go for fishing they carry with them the prepared food and consumed it at the fishing spot on the sea. Dinner was the mere repetition of the lunch. Snack is usually skipped by most nolias, instead they are seen to take early dinner.

Table.1 Average per capita daily food intake of fishermen community

\begin{tabular}{|l|l|c|c|c|}
\hline $\begin{array}{c}\text { Sl. } \\
\text { No. }\end{array}$ & \multicolumn{1}{|c|}{ Food group } & $\begin{array}{c}\text { Average per capita } \\
\text { daily intake (g) }\end{array}$ & $\begin{array}{c}\text { RDA (g) } \\
\text { ICMR 1988 }\end{array}$ & $\begin{array}{c}\text { Difference } \\
\text { from RDA (\%) }\end{array}$ \\
\hline $\mathbf{1 .}$ & Cereal & 791.07 & 550 & $(+) 43.83$ \\
\hline 2. & Pulses & 0.95 & 50 & $(-) 98.10$ \\
\hline $\mathbf{3 .}$ & Green leafy vegetable (GLV) & 9.38 & 100 & $(-) 90.62$ \\
\hline $\mathbf{4 .}$ & Fruits and vegetables & 72.57 & 100 & $(-) 27.43$ \\
\hline $\mathbf{5 .}$ & Roots and tubers & 41.50 & 60 & $(-) 30.83$ \\
\hline 6. & Milk and dairy products & 3.00 & 200 & $(-) 98.05$ \\
\hline 7. & Fat and Oil & 7.40 & 50 & $(-) 85.20$ \\
\hline 8. & Fish, meat and chicken & 52.24 & 50 & $(+) 4.48$ \\
\hline 9. & Sugar and jaggery & 7.46 & 30 & $(-) 75.13$ \\
\hline
\end{tabular}

Table.2 Correlation co-efficient between different food groups

\begin{tabular}{|c|c|c|c|c|c|c|c|c|c|c|}
\hline $\begin{array}{l}\text { Sl. } \\
\text { No. }\end{array}$ & $\begin{array}{c}\text { Food } \\
\text { group }\end{array}$ & Cereal & Pulse & GLV & $\begin{array}{c}\text { Fruits \& } \\
\text { vegetables }\end{array}$ & $\begin{array}{c}\text { Root \& } \\
\text { tubers }\end{array}$ & Milk & $\begin{array}{c}\text { Fat \& } \\
\text { Oil }\end{array}$ & Fish & Sugar \\
\hline 1 & Cereal & 1 & & & & & & & & \\
\hline 2 & Pulse & 0.149 & 1 & & & & & & & \\
\hline 3 & GLV & $0.447 * *$ & 0.079 & 1 & & & & & & \\
\hline 4 & $\begin{array}{l}\text { Fruits and } \\
\text { vegetables }\end{array}$ & 0.02 & (-) 0.303 & $(-) 0.027$ & 1 & & & & & \\
\hline 5 & $\begin{array}{l}\text { Roots \& } \\
\text { tubers }\end{array}$ & 0.21 & $0.339^{*}$ & 0.293 & (-)0.109 & 1 & & & & \\
\hline 6 & Milk & 0.167 & 0.182 & $0.035^{*}$ & 0.272 & $0.342 *$ & 1 & & & \\
\hline 7 & Fat \& Oil & 0.224 & 0.087 & 0.296 & $0.481 * *$ & 0.103 & 0.229 & 1 & & \\
\hline 8 & Fish & 0.204 & 0.137 & $0.339^{*}$ & $0.381^{*}$ & 0.132 & 0.202 & $0.972 * *$ & 1 & \\
\hline 9 & Sugar & 0.079 & (-) 0.202 & 0.056 & $0.324 *$ & $(-) 0.121$ & $0.402 *$ & 0.305 & 0.202 & 1 \\
\hline
\end{tabular}


Table.3 Average per capita daily nutrient intake of fishermen community

\begin{tabular}{|c|c|c|c|c|}
\hline $\begin{array}{l}\text { Sl. } \\
\text { No. }\end{array}$ & Nutrient type & $\begin{array}{l}\text { Average per capita } \\
\text { daily nutrient intake }\end{array}$ & $\begin{array}{c}\text { R.D.A.* } \\
\text { (NIN, 2011) }\end{array}$ & $\begin{array}{c}\text { Difference } \\
\text { from RDA }(\%)\end{array}$ \\
\hline 1 & Energy (kcal) & 3350.00 & 3490 & $(-) 4.00$ \\
\hline 2 & Protein (g) & 63.63 & 60 & (+) 6.05 \\
\hline 3 & Fat (g) & 13.84 & 40 & (-) 65.40 \\
\hline 4 & Calcium (mg) & 483.22 & 600 & (-) 19.46 \\
\hline 5 & Iron (mg) & 5.91 & 17 & (-) 65.23 \\
\hline 6 & $\beta$-Carotene $(\mu \mathrm{m})$ & 730.56 & 4800 & (-) 84.78 \\
\hline 7 & Thiamine (mg) & 1.47 & 1.70 & $(-) \quad 13.53$ \\
\hline 8 & Riboflavin (mg) & 1.82 & 2.10 & (-) 13.33 \\
\hline 9 & Niacin (mg) & 17.07 & 21 & $(-) \quad 18.71$ \\
\hline 10 & Folic acid $(\mu \mathrm{m})$ & 84.46 & 200 & (-) 57.77 \\
\hline 11 & Ascorbic acid (mg) & 13.59 & 40 & (-) 66.02 \\
\hline
\end{tabular}

* - As per NIN, 2011 for heavy worker (men)

\section{Average per capita daily food intake}

The mean daily per capita food intake of the sample population has been studied and has been compared with the recommended daily allowances prescribed by ICMR (1988) (Table 1). It is observed from the table that the intake of all the food stuffs are deficit from the recommended level with the only exception of cereals and fish. The intake of cereal was $40 \%$ surplus than RDA. Intake of green leafy vegetable, milk, sugar, jiggery, fat and oil was about $90 \%$ deficient from RDA. Similarly, intake of fruits, vegetables, roots and tubers was approximately $30 \%$ deficit from the recommended level. Intake of pulse was observed to be almost nil. However, the intake of fish was observed to be slightly above he recommended level for animal origin food (4.48\%), which may be substituting the deficient in intake of pulse to some extent (Table -1), since both serve as the source of protein.

Similar to our findings, Busi et al., (1987) has reported high consumption of cereals and fish by fishing group of Visakhapatnam coast. The consumption of pulses, oil and sugar was low, whereas that of vegetable, meat and egg was negligible. Contrary to this, Sidhu and Singh (1987) found the intake of food stuffs was more than RDA among the general population of Ludhiana district. Santhakumari and Sharada (1993) also observed similar findings among the vegetable grower and non-grower families. Mahajan et al., (1997) reported that the intake of pulse, fat and oil met with RDA among the population of Himachal Pradesh.

The correlation co-efficient among different food groups (Table-2) shows that there is positive correlation at 5\% level of significance in the intake pattern of root and tuber with pulse; root and tuber with milk; green leafy vegetable with milk; green leafy vegetable with fish etc.; fruit and vegetable with fish etc.; fruit and vegetable with sugar and jiggery; and milk with sugar and jaggery. Hence, it is observed that those who are taking pulse also using root and tuber to a significant level. The intake of green leafy vegetables is slightly correlated with the intake of fish, fat and oil and sugar and jiggery. A positive correlation is observed between the intake of root, tuber, sugar and jiggery. The correlation co-efficient is significant at $1 \%$ level of significance is case of intake of cereal with green leafy vegetable; 
fruit and vegetable with fat and fat with fish etc.

\section{Per capita daily nutrient intake}

Analysis of per capita daily nutrient intake of the sampled population (Table 3) shows that the intake of all the nutrients by the sampled population is less than that recommended daily allowance suggested by NIN (2011) with the only exception of protein and energy. Cereals followed by roots and tubers were the main food stuffs contributing to the energy content of the diet. Consumption of cereals was found to about $44 \%$ excess than the RDA (Table 1). Similarly, about 6\% surplus protein intake was observed in the sampled population (Table 3). The deficit in protein intake that would have resulted due to the lower consumption of other sources of protein e.g. pulses, milk, eggs, meat, chicken etc. might be getting compensated by the liberal consumption of fish (Table 1). Intake of fat and oil shows a deficit of about $65 \%$. Such a level of deficit was due to the negligible intake or total absence of fat containing food stuffs in the diet like milk and milk products, meat, poultry, nuts and oil seeds, besides the practice of using little amount of oil in all their preparations. Fat and oils, are consumed primarily as the source of essential fatty acid and other vital lipid fractions besides as a concentrated source of energy. The energy deficit that would have arisen due to low intake of fat might be getting adjusted due to high consumption of cereals. However, the purpose of consumption fat and oil as the source of other vital nutrients remains unattended in the Nolia diet.

A high level of deficiency in iron (i.e. above $65 \%$ ) and Calcium (19.46 \%) level was seen in the diet of the fishermen community of sample area. Such a high level of deficiency may be contributed by the negligible intake of fruit and vegetable as well as green leafy vegetables. However, the liberal consumption of small fish with their bones may be attributed to compensate the Calcium deficit to some extent.

A huge deficit in the intake of vitamins has been observed among the sample population. $730.56 \mu \mathrm{g}$ of $\beta$-carotene intake was observed against the $4800 \mu \mathrm{g}$ recommended level, indicating about $85 \%$ deficient. (Table 3). Minimal intake of carotene containing food like green leafy vegetable, coloured fruits and vegetables by the fishermen community of sample area may be one of the contributing factor for such a high level of deficiency.

About $13.53 \%$ deficit in case of thiamine intake was observed and that for riboflavin and niacin was $13.33 \%$ and $18.71 \%$, respectively. However, the deficiency of folic acid and ascorbic acid was about $57.77 \%$ and $66.02 \%$, respectively (Table 3 ). In spite of the liberal consumption of fish, the deficiency in case of vitamin B complex and ascorbic acid may be due to the lower or negligible intake of protective foods like fruit, vegetable and green leafy vegetables.

From this analysis it can be concluded that the diet of sample population was deficient in all the nutrients, with the only exception of energy and protein. The finding of this study was in agreement with Busi et al., (1987), who had found a high level of protein and energy in the diet of fishermen community of Visakhapatnam district, while their calcium and iron intake were equal to the RDA. The present study shows that the diet of sample population is inadequate both qualitatively and quantitatively for most of the nutrients. Similar observation were made by Sahu and Mohapatra (1989) from their study on the tribals of Sundargarh and by Patro et al., (2011) on tribal pre-school children of Koraput dist of Odisha. Less calorie intake by the rural population of Tamil Nadu and 
primitive tribes of Bihar was observed by Sadasivam et al., (1980) and Gupta (1980), respectively. Tiwari (1989) also concluded their studies in the similar lines from his studies in the Sagar district of Madhya Pradesh. Srinath (1989) also made similar observations on the food consumption pattern and nutritional status of marine fishermen community. On the other hand, Arora (1992) observed a high intake of all the nutrients by the people of Gwalior city.

\section{References}

Arora, A., 1992. A study on the food and nutritional intake status in Gwalior city. The Ind. J. Nutr. Dietet., 29(10): 321 - 329 pp.

Bijayalakshmi D.N. and Ajitkumar, N., 2014.Socioeconomic conditions and cultural profile of the fishers in India a review. IOSR Journal of Agriculture and Veterinary Science; 7(9): 42-48 pp.

Belton, B. and Thilsted, S.H., 2014. Fisheries in transition: Food and nutrition security implications for the global South. Global Food Security, 3: 59-66 pp.

Busi, B.R., Masai, N., Babu, A.D.W.R. and Jyothi, G.M., 1987. Food, dietary intake and feeding practices in urban slums of Visakhapatnam. The Ind. J. Nutr. Dietet., 24(6): 136 - 142 pp.

Gopalan, C., Ramashastri, B.V., Balsubramanian, S.C., Rao, B.S.N., Deosthale, Y.G., and Pant, K.C., 1989. Nutritive Value of Indian Foods (Revised Edn.)., National Institute of Nutrition, Hyderabad, 48 pp.

Gupta, S. P., 1980. Nutrition and health problems in primitive tribal groups of Chottanagpur and Santhal Praganas (Bihar).

ICMR, 1988. Recommended Daily Allowances of Nutrients and Balance diets. ICMR Nutrition Advisory Committee, 3 pp.

Kent, G., 1987. Fish, Food and Hunger; The Potential of Fisheries for Alleviating Malnutrition. West View Press, Colorado, USA.

Mahajan, N., Kalia, M. and Katania, S.R., 1997. Food consumption by rural population of selected areas of Mandi district of Himachal Pradesh. J. Rural Dev., 16(1): 167 -172 pp.

NIN, 2011. Dietary Guidelines for Indians A Manual. National Institute of Nutrition (ICMR), Hyderabad, 127pp.

Pal, B., Chattopadhay, M., Maity, M., Mukhopadhayay, B. and Gupta, R., 2011. Income and nutritional status of the fishing community residing in coastal bay of Bengal; a case study. Anthrop. Anz. 68(2): 195 -208 pp.

Patro, S., Nanda, S. and Samantaray, P. (2011). Impact of socio-economic factors on nutritional status of tribal pre-school children. Asian J. of home Sc., 6(1); 88-92 pp.

Prabhavathi K. and Krishna, P.V., 2017. Socio-economic conditions of fishermen community in some selected areas of Nizampatnam area, Guntur district, Andhra Pradesh, India. International Journal of Zoology Studies., 2(5): 212-215 pp.

Sadasivam, S., Kasturi, R. and Subramanian, S., 1980. Nutritional survey in a village of Tamil Nadu. The Ind. J. Nutr. Dietet., 117(7): 245 - 249 pp.

Sahu, B. and Mohapatra, K. (1989). Industrialisation and changing pattern of socio-economic life of tribals - A case study in the Lathikata region of Sundargarh district. In; Tribals of Odisha - The Changing SocioEconomic Profile. Ray, B.C. (ed.). Gian Publ. House, New Delhi, 103 pp.

Sandaruwan K.P.G.L., De Silva D.W.L.U. and Amarala K.H.M.L (2016). A 
study of food consumption pattern, food culture and nutritional status of the multi-day fishermen of Sri Lanka. Third International Research Symposium, Rajarata University of Sri Lanka

Santhakumari, B. and Sharada, D., 1993. Food and nutrient intake of vegetable grower families. The Ind. J. Nutr. Dietet., 30(12): 332- 336pp

Sehera DB, JP Karbhari, Sathiadas R., 1986. A study on the socio-economic conditions of fishermen in some selected villages of Maharastra and Gujarat coast Mar. Fish. Inf. Serv. Tech. Ext. Ser., 69:1-18.

Sidhu, H. K. and Singh, I., 1987. A study of nutritional status of farmers of Ludhiana district. J. Res. Punjab. Agril. Univ., Ludhiana.

Singh H.R., Payne, A.L., Katha, P.K., Singh, P.R. and Pandey, S.K., 1995. Social status and problems of fishing community at Allahabad: J. Indian. Fish. Assoc.; 25:83-92.

Srinath K., 1989. Psycho - social aspects of fishermen with respect of motorization. Mar. Fish. Ind. Ser. Tech. Ext. Ser., 89:13-15.

Swaminathan, M.S., 1988. Food and Nutrition, Vol. I. The Bangalore Printing and Publishing Co. Ltd., No. 88, Mysore Road, Bangalore- 560001, $232 \mathrm{pp}$

Tacon, A.G.J. and Metian, M., 2013. Fish matters: importance of aquatic foods in human nutrition and global food supply. Rev. Fish. Sci., 21(1), 22-38 pp.

Tiwari, P.D., (1989). Some aspects of health and nutrition in India. A case study of Sagar district (Madhya Pradesh). In: Modern Trends in Anthropology. Sharma, A.N. (ed.). Northern Book Centre, New Delhi, 171 pp.

\section{How to cite this article:}

Suryamani Patro, Brundaban Sahu and Bikash Kumar Pati. 2020. Food Consumption Pattern and Nutrient Intake by the Fishermen Community of Ganjam District, Odisha. Int.J.Curr.Microbiol.App.Sci. 9(12): 672-680. doi: https://doi.org/10.20546/ijcmas.2020.912.081 